c） A,B配合油のままの形で両者ともと牛脂主体ブ レンド型, Cは製品（ショートニング）の形でヤシ油ナ タネ油主体ブレンド型.

d) Distillation Products industries (D P I) 製品 Myverol No. 18-05.

\section{5. 総括}

1. ショートニングの代表的性質の一つであるクリー ミング性について研究を行つた。

2. 市販のショートニング 11 種とついてクリーミン グ価を測定した結果, 大体 200〜350 でありて, バター, マーガリンよりはるか、優れていた。

3. 製品と原料油の間には 20〜30\% の差が認められ た。

4. 製品は適当な温度に捻いては熟成の効果著しくた

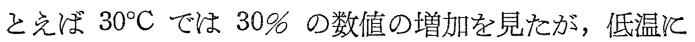
特いてね死とんどその効果は認められなかつた。

5. 油脂の種類による相違について全水添型硬化油 （牛脂はとのます）の型で試験した結果ヤシをのぞく一 般植物油（ここでねナタネ, ワタミ, ダイズ油）は動物 油脂（鯨油，牛脂）よりる一般に良好な結果を与えた。
6. 水添の程度は笑用範囲では良好で，またとの範囲 内では余り影響はないが，軽度括よび高度の場合は悪 くほほをえぞ抱気性を認められなかつた。

7. 乳化刪としてのモノグリセリドの添加は明かな効 果を示し，またとの量を増すほで抱気性のみでなく持続 性子堌加した。

終りに本研究の発表を許可された日本油脂株式会社野 崎常務に詨し深謝の意を表する。

(昭和 29 年 11 月 29 日受理)

文献

1) A.E. Bailey, R.H. Mckinney, Oil and Soap, 18, 120-122(1941).

2) A.E. Bailey, "Industrial Oil and Fat Products", 2 nd. Ed., p. 300 302(1951).

3) J.A. Dunn, J.R. White, Cereal Chemistry, 14, 783 801(1937).

4) R.O. Feuge, A.E. Bailey, Oil and Soap, 21, 78 84(1944).

5) M. B. Jacobs, "Synthetic Food Adjuncts", p. 2 53, Nostland Co., New York (1946).

6) A.E. Bailey, "Industrial Oil and Fat Products", 2 nd Ed., p. 257(1951).

\title{
トール油に関する研究(第3 報)
}

本邦座トール油中の二, 三のテルペンについて

伊藤 舜介*。松本太郎*

Tall Oils. III.

On Some Terpenes from the Japanese Tall Oil.

Shunsuke Ito and Taro Matsumoto

\section{緒言}

木材中のテルペンはパルプ製造の際の蒸解操作によつ て分離し得る(硫酸塩法テレビン油 Sulfatterpentinö1)。 そのテルペン成分は主として原材炕由来しているが，一 部は化学変化市を受けているととも考光られる。

本邦の赤松材のテルペン成分あるいは蒸解操作を経た テルペン成分とついての研究は医とえで発表されていな い。著者らは本邦のトール油について研究し, 不ケン化 物中《 $0.7 \sim 7.9 \%$ 程度（試料 10 種）の揮発性テルペ ンが含まれているととがわかつたが，今回とくとテルペ ンの留出を防いで生成された赤松のトール油を入手した

* 日本大学工学部工業化学教室(東京都千代田区神田 駿河台)

Department of Industrial Chemistry, Faculty of Engineering, Nihon University.
ので，これより揮発性テルペンを分離してその成分を研 究した。

\section{実験およびその結果}

本研究用いたトール油は京都府福知山付近産の赤松 を原料として $165^{\circ} \mathrm{C} ， 1$ 時間蒸解して生成された製紙工 場のもので，これより不ケン化物をエーテル抽出し，水 蒸気蒸留して不ケン化物の $18.9 \%$ の揮発性油状物質を 得た。その性状はつぎのごとくである。

$d_{4}^{20} 0.8878, n_{\mathrm{D}}^{20} 1.4723,[\alpha]_{\mathrm{D}}^{10}=+8(1.5 \%$ クロロホ ルム溶液)，ケン化価 0

この油状物質 $50 \mathrm{~g}$ をクライゼンフラスコにて分留す ると表一1 のごとき結果を得る。

表一1 の留分 2 (20 g) はふた它び蒸留すると 表一2 のごとき結果を得る。

※ーピネン: 表一2 の留分 2 ほさらと精留して沸点 $153^{\circ}$ 


\begin{tabular}{c|r|r|c|c|c}
\multicolumn{9}{c}{ 表一 1} \\
\hline 留分 & $\begin{array}{c}\text { 留出温 } \\
\left({ }^{\circ} \mathrm{C}\right)\end{array}$ & 収量 $(\%)$ & $d_{4}^{20}$ & $n_{\mathrm{D}}^{20}$ & {$[\alpha]_{\mathrm{D}}^{15}$} \\
\hline 1 & $\sim 150$ & 1 & - & - & - \\
2 & $150 \sim 160$ & 41 & 0.8515 & 1.4621 & -30 \\
3 & $160 \sim 175$ & 30 & 0.8584 & 1.4713 & +15 \\
4 & $175 \sim 240$ & 16 & 0.9346 & 1.4829 & +18 \\
5 & $240 \sim 250$ & 11 & 0.9369 & 1.5009 & +31 \\
残留物 & & 1 & - & - & - \\
\hline
\end{tabular}

\begin{tabular}{c|r|r|c|c|c}
\multicolumn{7}{c}{ 表一2 } \\
\hline 留分 & $\begin{array}{c}\text { 留出温度 } \\
\left({ }^{\circ} \mathrm{C}\right)\end{array}$ & 収量 $(\%)$ & $d_{4}^{20}$ & $n_{\mathrm{D}}^{20}$ & {$[\alpha]_{\mathrm{D}}^{15}$} \\
\hline 1 & $\sim 154$ & 2 & - & 1.3972 & - \\
2 & $154 \sim 158$ & 85 & 0.8506 & 1.4631 & -36 \\
3 & $158 \sim 161$ & 8 & 0.8593 & 1.4672 & -20 \\
残留物 & & 5 & - & - & - \\
\hline
\end{tabular}

$\sim 155^{\circ} \mathrm{C}$ の留分 (収量 $50 \%, d_{4}^{20} 0.8533 ， n_{\mathrm{D}}^{20} 1.4635$, $[\alpha]_{\mathrm{D}}^{20}=-47$ ) を得, これに金属ナトリウムを加兄て減 㞋蒸留して沸点 $46^{\circ} \sim 47^{\circ} \mathrm{C} / 3 \mathrm{~mm} \mathrm{Hg}$ の留分 (8 g) を得 る。

この留分飞亜硝酸エチル $5 \mathrm{~g}$ を加觉て冷却下 $\left(-10^{\circ} \mathrm{C}\right)$ 飞塩化水素を飽和させた冷エチルアルコール溶液 $15 \mathrm{cc}$ を徐々に加觉ると釬状結晶 $3.1 \mathrm{~g}$ を得る（ニトロソクロ リド)。この結晶の一部 $(1.3 \mathrm{~g})$ とベンジルアミンのエ チルアルコール溶液を加光て湯浴上に加熱して後, 水を 加えて冷却すると釬状結晶 $(0.9 \mathrm{~g})$ を得る。これは石油 エーテルで分別結晶を行うと融点 $122^{\circ} \mathrm{C}$ の針状結晶 (10 $\mathrm{mg})$ と融点 $85^{\circ} \mathrm{C}$ の釬状結晶 $(0.5 \mathrm{~g})$ を得, 融点 122 ${ }^{\circ} \mathrm{C}$ の結晶は著者らがさき飞黒松根油より得た純不活性 のーピネンより製した不活性 一

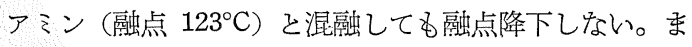
た融点 $85^{\circ} \mathrm{C}$ の結晶ほ同様と赤松根油より得た純 $l-\alpha-$ ピネンより製した $l-\alpha$ ピネンニトロルベンジルアミン (融点 $84^{\circ} \mathrm{C}$ ) そ㫽融して子融点降下しない。

つぎに上記のニトロソクロリド $(1.2 \mathrm{~g})$ にピペリジン (3g) をエチルアルコールの存在で反応させると微細な 結晶 $(0.8 \mathrm{~g})$ を得る。これは石油エーテルで分別結晶を 行うと融点 $145^{\circ} \sim 146^{\circ} \mathrm{C}$ の釬状結晶 $(5 \mathrm{mg}$ ) そ融点 120 ${ }^{\circ} \mathrm{C}$ の結晶 $(50 \mathrm{mg})$ を得る。前者は黒松根油よりの純不 活性 $-\alpha$-ピネンニトロルピペリジン（融点 $145^{\circ} \mathrm{C}$ ) と, 後者は赤松根油よりの純 $l$ - $\alpha$ ーピネンニトロルピペリジン

(融点 $117^{\circ} \mathrm{C}$ ) そ混融しても融点降下しない。

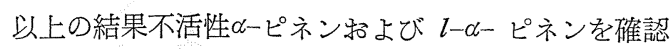
したが不活性 $\alpha$-ピネンニトロソクロリドはしばしば実

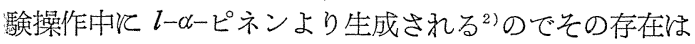
な和検討を要する。

カンフェン: 表一2 の留分 2 を精留して沸点 $153^{\circ} \sim$ $155^{\circ} \mathrm{C}$ 留分をのぞいた残留物に表一2 の留分 3 を合せて 蒸留すると沸点 $159^{\circ} \sim 162^{\circ} \mathrm{C}$ の留分 $\left(1.5 \mathrm{~g}, d_{4}^{20} 0.8593\right.$, $\left.n_{\mathrm{D}}^{20} 1.4652,[\alpha]_{\mathrm{D}}^{15}=-20\right)$ を得る。これはカンフェン臭 を有するので酶酸 ( $3.8 \mathrm{~g})$ 特よび $50 \%$ 硫酸 $(0.5 \mathrm{~g})$ を 加党て $50^{\circ} \sim 60^{\circ} \mathrm{C}$ で 3 時間攪挥乙て反応させ，その生成 物を水酸化カリウムーエチルアルコールでケン化して水 蒸気蒸留して留出物を捕集する。これを石油エーテルで 再結晶を行うと融点 (封管中) $208^{\circ} \sim 209^{\circ} \mathrm{C}$ の板状結晶 (60 mg) を得るが，乙れは純カンフェン（融点 $48^{\circ} \sim 49$ ${ }^{\circ} \mathrm{C}$ ) より作られたイソボルネオール（封管中の融点 212 $\left.{ }^{\circ} \mathrm{C}\right)$ と混融しても融点降下しない。をたこのもののフェ ニルウレタンは融点 $137^{\circ} \sim 138^{\circ} \mathrm{C}$ を示す。

Bーピネン: 表一1 の留分 3 はさらに分留してつぎのご そき結果を得た（表一3）。

\begin{tabular}{c|r|r|c|c|c}
\multicolumn{7}{c}{ 表一3 } \\
\hline 留分 & $\begin{array}{c}\text { 留出温度 } \\
\left({ }^{\circ} \mathrm{C}\right)\end{array}$ & 収量 $(\%)$ & $d_{4}^{20}$ & $n_{\mathrm{D}}^{20}$ & {$[\alpha]_{\mathrm{D}}^{15}$} \\
\hline 1 & $\sim 161$ & 3 & 0.8559 & 1.4663 & -19 \\
2 & $161 \sim 168$ & 87 & 0.8586 & 1.4700 & +16 \\
3 & $168 \sim 178$ & 9 & 0.8613 & 1.4737 & +16 \\
残留物 & & 1 & - & & \\
\hline
\end{tabular}

この留分 2 ふたたび分留して沸点 $163^{\circ} \sim 165^{\circ} \mathrm{C}$ の留 分(収量 $55 \%, d_{4}^{20} 0.8645, n_{\mathrm{D}}^{20} 1.4733,[\alpha]_{\mathrm{D}}^{20}=+5$ ) を得, これマ金属ナトリウムを加えて減圧蒸留して精製し, 留 出物 $(9 \mathrm{~g})$ を過マンガン酸カリウム $(25 \mathrm{~g})$ と水酸化力 リウム $(5 \mathrm{~g})$ の水溶液 $(300 \mathrm{cc})$ で 30 分璒拌して酸化 した後, 未反応物を水蒸気蒸留しての导き, 残液を濃縮 乙て析出する結晶と母液とを分ける。結晶名石油エーテ ルにとかし酸で分解して再結晶すると融点 $125^{\circ} \sim 126^{\circ} \mathrm{C}$ の釬状結晶 $(0.3 \mathrm{~g})$ を得る。これはノピン酸の融点（文 献值 ${ }^{3}$ 融点 $126^{\circ} \sim 128^{\circ} \mathrm{C}$ ) 飞一致する。おたこの結晶は 酰酸と過酸化鉛で酸化してとのセミカルバゾーンを作る そ融点 $186^{\circ} \sim 187^{\circ} \mathrm{C}$ の微細な結晶が得られる。また母液 よりは融点 $70^{\circ} \mathrm{C}$ の柱状結晶数 $\mathrm{mg}$ が得られピノン酸の 融点 (文献值 ${ }^{3}$ 融点 $68^{\circ} \sim 69^{\circ} \mathrm{C}$ ) 飞一致している。以上 の結果 $\beta$-ピネンそ混在する $\alpha$-ピネンの存在が認められ る。

p-サイメン: 表一3 の留分 2 を精留して沸点 $163^{\circ} \sim$ $165^{\circ} \mathrm{C}$ の留分をのぞいた残留物特よび表一2 の留分 2 を 精留して沸点 $153^{\circ} \sim 155^{\circ} \mathrm{C}$ の留分をのぞいた残留物に表 一2 の留分 3 を合世て蒸留して沸点 $159^{\circ} \sim 162^{\circ} \mathrm{C}$ の留分 をのぞいた残留物を合せて蒸留し，沸点 $173^{\circ} \sim 175^{\circ} \mathrm{C} の$ 留分 $(5.3 \mathrm{~g})$ を得た。との留分は で $2 \%$ 過マンガン酸カリウム溶夜で処理して, その一部 (3g) 飞硫酸 $(10 \mathrm{~g})$ を加え湯浴上で加熱して $p$-サイメ ン臭がなくなればこれを水中にとそぎ炭酸バリウムで中 和し, 析出する結晶を除去して母液を濃縮すると板状結 
晶 $(1.53 \mathrm{~g})$ を得る。これは $105^{\circ} \mathrm{C} て ゙$ 乾燥すると 8.87 $\%\left(\left(\mathrm{C}_{10} \mathrm{H}_{13} \mathrm{SO}_{3}\right)_{2} \mathrm{Ba} \cdot 3 \mathrm{H}_{2} \mathrm{O}\right.$ の理論結晶水含量 $\left.8.75 \%\right)$ の重量減少をなし, $\mathrm{Ba} 24.31 \%\left(\left(\mathrm{C}_{10} \mathrm{H}_{13} \mathrm{SO}_{3}\right)_{2} \mathrm{Ba}\right.$ の 理論 $\mathrm{Ba}$ 含量 $24.33 \%$ ) である。またこの留分 $(2 \mathrm{~g}) を$ 過マンガン酸カリウム溶液 $(12 \mathrm{~g} / 350 \mathrm{cc})$ で 6 時間還流 加熱乙て後, 未反応物を水蒸気蒸留除去して残留物を湯 浴上で蒸発乾固してェチルアルコールで処理し希硫酸で 分解して $70 \%$ エチルアルコールで再結晶すると融点 $156.5^{\circ} \mathrm{C}$ の柱状結晶 $(50 \mathrm{mg})$ を得る。これね純 $p$-サイ メンより得られた $\left.155^{\circ} \mathrm{C}\right)$ と混融して子融点降下しない。

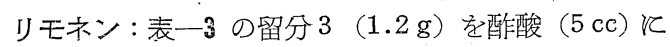
溶解し冷却下冷臭素を滴下し反応生成物を酢酸エチル にて再結晶を行うと融点 $123^{\circ} \mathrm{C}$ の板状結晶数 $\mathrm{mg}$ 物よ び $103^{\circ} \sim 104.5^{\circ} \mathrm{C}$ の板状結晶 $(20 \mathrm{mg})$ を得る。後者は 純りモネンより作られた臭化物（融点 $104^{\circ} \sim 105^{\circ} \mathrm{C}$ ) と 混融しても融点降下しない。前者はジペンテンと認めら れる。

$\alpha$-テルピネオール : 表一1 の留分 4 ほさらと減圧蒸留 して4 留分分けた。その性状々つぎのごとくである。

\section{表-4}

\begin{tabular}{c|c|c|c|c|c}
\hline 留分 & $\begin{array}{c}\text { 留出温度 } \\
\left({ }^{\circ} \mathrm{C} / 5 \mathrm{~mm}\right)\end{array}$ & $\begin{array}{c}\text { 収量 } \\
(\%)\end{array}$ & $d_{4}^{20}$ & $n_{\mathrm{D}}^{20}$ & {$[\alpha]_{\mathrm{D}}$} \\
\hline 1 & $\sim 55$ & 2 & - & 1.4779 & - \\
2 & $55 \sim 85$ & 5 & 0.9286 & 1.4792 & - \\
3 & $85 \sim 90$ & 80 & 0.9356 & 1.4821 & +17 \\
4 & $90 \sim 95$ & 10 & 0.9362 & 1.4873 & +17 \\
残留物 & & 3 & - & - & - \\
\hline
\end{tabular}

この留分 3 握よび4 (2g) をさきの そ同様の操作によつてニトロルピペリジンを作ると融点 $157^{\circ} \sim 158^{\circ} \mathrm{C}$ の微細な結晶 (数 $\mathrm{mg}$ ), 和よび融点 $154^{\circ} \mathrm{C}$ の結晶 $(10 \mathrm{mg})$ を得る。前者は不活性テルピネオール ニトロピペリジンの融点 (文献值 ${ }^{4)}$ 融点 $159^{\circ} \sim 160^{\circ} \mathrm{C}$ )

V, 後者は活性のものの融点 (文献值 ${ }^{4}$ ) 融点 $151^{\circ} \sim 152$ $\left.{ }^{\circ} \mathrm{C}\right)$ に応一致する。また留分 3 犒よび $4(2 \mathrm{~g})$ は希過 マンガン酸カリウム溶液 (3\%) で酸化すると融点 $120^{\circ}$ $\sim 121.5^{\circ} \mathrm{C}$ の微細な結晶 $(0.1 \mathrm{~g})$ が得られる。これは 1,2,8-トリオキシテルペンの融点 (文献值 ${ }^{4)}$ 融点 $121^{\circ}$ $\sim 122^{\circ} \mathrm{C}$ ) 飞一致する。

ロンギフォーレン: 表一1 の留分 5 をさらに減圧蒸留 してつぎの3留分に分けた。

\section{表一5}

\begin{tabular}{c|c|c|c|c|c}
\hline 留分 & $\begin{array}{c}\text { 留出温度 } \\
\left({ }^{\circ} \mathrm{C} / 6 \mathrm{~mm} H \mathrm{H}\right)\end{array}$ & $\begin{array}{c}\text { 収量 } \\
(\%)\end{array}$ & $d_{4}^{20}$ & $n_{\mathrm{D}}^{20}$ & {$[\alpha]_{\mathrm{D}}^{20}$} \\
\hline 1 & $\sim 95$ & 6 & - & 1.4993 & - \\
2 & $95 \sim 105$ & 82 & 0.9353 & 1.5031 & +36 \\
3 & $105 \sim 110$ & 7 & 0.9381 & 1.5036 & +40 \\
残留物 & - & 5 & 0.9387 & 1.5040 & - \\
\hline
\end{tabular}

留分 2 ほロン゙フォーレンの性状に一致しているの で，これそ金属ナトリウムを加光て減圧蒸留して精製 し，との一部 $(2 \mathrm{~g})$ をエーテル溶液で強冷下に臭化水素 を飽和させて後エーテルを追つて生成物を酢酸エチルー アルコールで再結晶すると融点 $68^{\circ} \sim 70^{\circ} \mathrm{C}$ の微細な結晶 (0.2 g) を得る。これはロンギフォーレンヒドロブロミ ドの融点 (文献值 ${ }^{5}$ ) 融点 $69^{\circ} \sim 70^{\circ} \mathrm{C}$ ) 飞一致する。むた 精製した留分の一部 $(2 \mathrm{~g})$ をエーテル溶夜で強冷下に塩 化水素を作用させて生じた生成物はェチルアルコールよ りの再結晶で融点 $58^{\circ} \sim 60^{\circ} \mathrm{C}$ の微細な結晶 $(0.11 \mathrm{~g})$ で あり，これはロンギフォーレンヒドロクロリドの融点 (文献值 ${ }^{5}$ ) 融点 $59^{\circ} \sim 60^{\circ} \mathrm{C}$ ) 飞一致する。

\section{総 括}

赤松材のクラフト蒸解操作を受けたテルペンをとのト 一ル油加ら水蒸気蒸留して分離したものについて, 沸点 $153^{\circ} \sim 155^{\circ} \mathrm{C}$ の留分から ひ-ピネンを認め，これがテル ペン成分の大半 (約 $40 \%$ ) を占めて呿り，また他の成分 乙して沸点 $163^{\circ} \sim 165^{\circ} \mathrm{C}$ の留分から $\beta$-ピネン（約 $8 \%$ ) を, 浑点 $158^{\circ} \sim 161^{\circ} \mathrm{C}$ の留分からカンフェン（約 $5 \%$ ) を, 苏点 $168^{\circ} \sim 178^{\circ} \mathrm{C}$ の留分からリモネン（約 $3 \% ）$ を, 沸点 $173^{\circ} \sim 175^{\circ} \mathrm{C}$ の留分から p-サイメン（約 $10 \%$ ) を, 沸点 $85^{\circ} \sim 95^{\circ} \mathrm{C} / 5 \mathrm{~mm} \mathrm{Hg}$ の留分からいーテルピネオ 一ル (約 15\%) を，呿よび沸点 $95^{\circ} \sim 105^{\circ} \mathrm{C} / 6 \mathrm{mmHg}$ の 留分からロンギフォーレン（約 $8 \%$ ）を認めた。

(昭和 29 年 11 月 30 日受理)

$$
\text { 文献 }
$$

1) たとえばめーピネン，ジペンテンは $\mathrm{S}, \mathrm{SO}_{2}$ の存在 で p-サイメンに変る. O. Routala, A. Pohjola, Chem. Abst., 28, 4227(1934).

2) E.V. Lynn, J. Am. Chem. Soc., 41, 361(1919).

3) O. Wallach, Ann., 356, 228(1907).

4) O. Wallach, Ann., 277, 120(1893), 360, 90 (1908).

5) J.L. Simonsen, J. Chem. Soc., 117, 570(1920). 